Barbara HAUREZ ${ }^{1,2}$

Yves BRostauX ${ }^{3}$

Charles-Albert Petre ${ }^{1,4,5}$

Jean-Louis DOUCET ${ }^{1,2}$

1 University of Liège Gembloux Agro-Bio Tech Laboratory of Tropical Forestry

Passage des Déportés 2

5030 Gembloux

Belgium

2 École Régionale Post-Universitaire d'Aménagement et de Gestion Intégrés des Forêts et Territoires Tropicaux (ERAIFT)

Kinshasa

Democratic Republic of Congo

${ }^{3}$ University of Liège Gembloux Agro-Bio Tech Statistics, Informatics and Mathematics

Passage des Déportés 2

5030 Gembloux

Belgium

${ }^{4}$ Centre for Research and Conservation, Royal Zoological Society of Antwerp (RZSA)

Projet Grands Singes (PGS)

Belgium

${ }^{5}$ Royal Belgian Institute of Natural Sciences Conservation Biology Unit

Section Education and Nature

Passage des Déportés 2

5030 Gembloux

Belgium

\section{Is the western lowland gorilla a good gardener? Evidence for directed dispersal in Southeast Gabon}

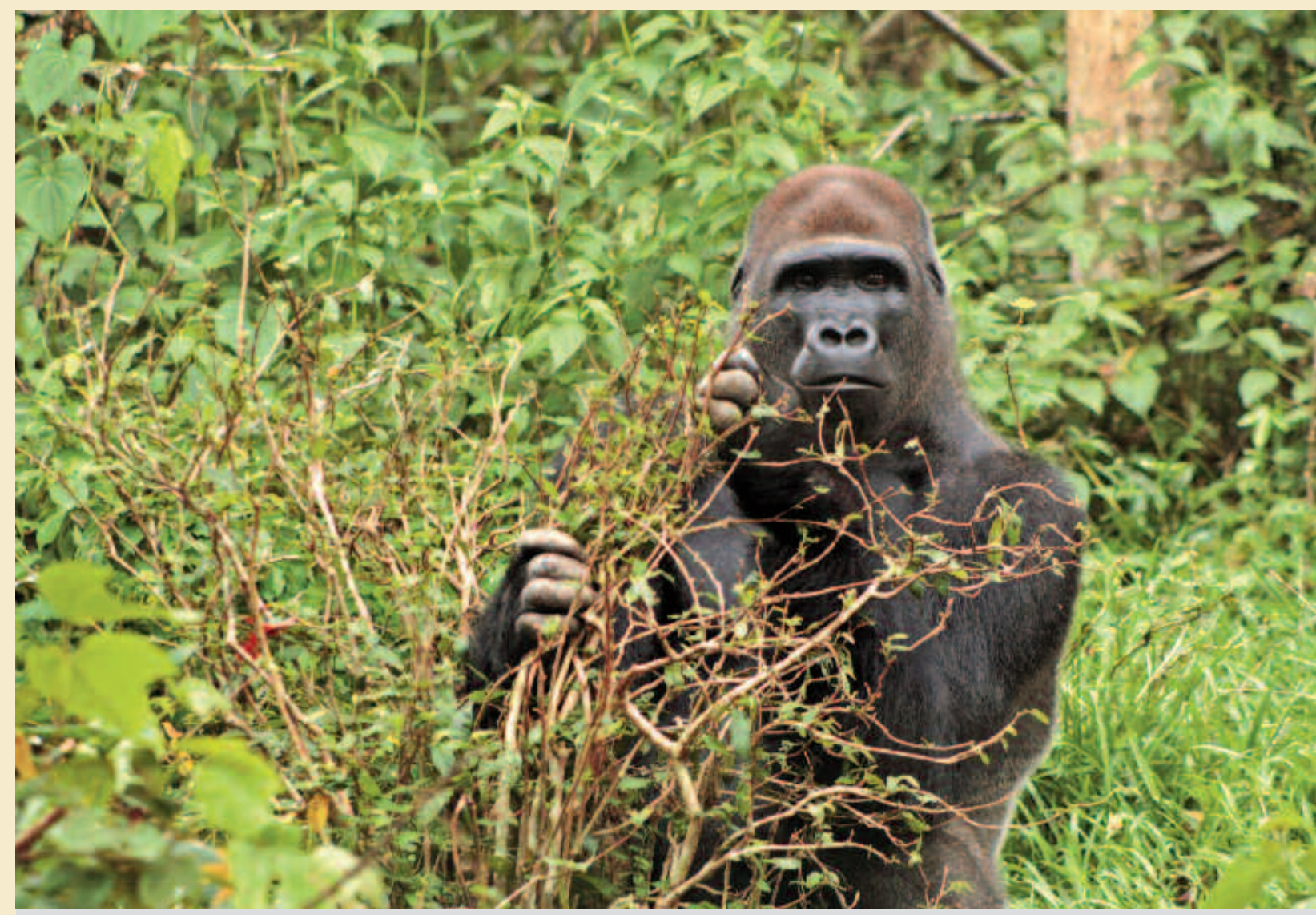

Photo 1.

Western lowland gorilla.

Photograph J.-Y. De Vleeschouwer. 


\section{LE GORILLE EST-IL BON JARDINIER ? PREUVES DE L'EXISTENCE DE DISPERSION DIRIGÉE AU SUD-EST DU GABON}

Dans les forêts tropicales d'Afrique centrale, le gorille des plaines occidentales dépose la plupart des graines qu'il disperse dans des nids bien éclairés propices à la croissance de plantules, laquelle est susceptible d'être renforcée par l'effet fertilisant des matières fécales entourant les graines. Cet effet fertilisant n’avait jamais été testé. Notre étude visait ainsi à déterminer si le dépôt de graines par les gorilles (i) dans une matrice fécale et (ii) dans leurs nids présente un avantage pour le développement des plantules (taux de croissance et de foliation) et pour leur survie (\% de plantules survivantes). Pour évaluer l'effet de la matrice fécale, des graines de Santiria trimera (Burséracée), Chrysophyllum lacourtianum (Sapotacée) et Plagiostyles africana (Euphorbiacée) recueillies dans des déjections de gorilles ont été semées en pépinière avec et sans matrice fécale. Des plantules de Santiria trimera et Dacryodes normandii (Burséracées) ont été installées dans des nids et en forêt de terra firme à couvert fermé afin d'évaluer l'impact du dépôt de graines sur le développement et la survie des plantules. Nos observations montrent une influence positive de la matrice fécale sur le développement des plantules des essences étudiées, mais aucun effet sur leur survie. Concernant les sites de dépôt, les taux de croissance observés étaient de deux à dix fois plus élevés dans les nids qu'en forêt à couvert fermé. Le développement accru des plantules est corrélé positivement avec l'ouverture du couvert forestier. Des études in situ de la germination et de la croissance et la survie des plantules sont nécessaires pour mieux caractériser le destin des graines dispersées par les gorilles. Cependant, nos résultats tendent à prouver que les gorilles jouent un rôle de dispersion dirigée important dans les forêts à couvert ouvert.

Mots-clés: Gorilla gorilla gorilla, effet fertilisant, dispersion dirigée, comportement de nidification, dispersion des graines, croissance des plantules, survie des plantules, Gabon.

\section{IS THE WESTERN LOWLAND GORILLA A GOOD GARDENER? EVIDENCE FOR DIRECTED DISPERSAL IN SOUTHEAST GABON}

In Central African tropical forests, the western lowland gorilla deposits most of the seeds it disperses in well-lit nesting sites that can favour seedling growth. The faecal matrix surrounding the seeds can act as a fertiliser and further enhance seedling development. This fertilisation effect had never been tested. Our research therefore aimed to determine whether seed deposition by gorillas (i) in faecal matter and (ii) in nest sites is advantageous for seedling development (growth rate and foliation rate) and survival (\% of surviving seedlings). To assess the effect of the faecal matrix, seeds of Santiria trimera (Burseraceae), Chrysophyllum lacourtianum (Sapotaceae) and Plagiostyles africana (Euphorbiaceae) collected from gorilla faeces were sown in a nursery with and without a faecal matrix. Seedlings of Santiria trimera and Dacryodes normandii (Burseraceae) were established in nest sites and in closed canopy terra firme forest sites to assess the impact of seed deposition on seedling development and survival. The faecal matrix was observed to positively influence seedling development in the species studied, but showed no effect on survival. Regarding seed deposition sites, the development rates observed were two to ten times higher in the nest sites than in closed-canopy forest. This enhanced seedling development was positively correlated with canopy openness. In situ studies of seed germination, seedling growth and survival are needed to characterise the fate of gorilla-dispersed seeds more precisely. However, our results offer evidence that gorillas provide important directed dispersal services by depositing seeds most frequently in open canopy sites.

Keywords: Gorilla gorilla gorilla, fertilisation effect, directed dispersal, nesting behaviour, seed dispersal, seedling growth, seedling survival, Gabon.

\section{RESUMEN}

\section{¿EL GORILA ES UN BUEN JARDINERO? PRUEBAS DE LA EXISTENCIA DE DISPERSIÓN DIRIGIDA EN EL SUDESTE DE GABÓN}

En los bosques tropicales de África Central, el gorila de llanura occidental deposita la mayoría de las semillas que dispersa en nidos bien iluminados que favorecen el crecimiento de las plántulas. Este crecimiento podría verse reforzado por el efecto fertilizante de la materia fecal que rodea las semillas. Dicho efecto fertilizante nunca se había evaluado. Por ello, el objetivo de nuestro estudio consistía en determinar si la deposición de semillas por los gorilas (a) en una matriz fecal y (b) en sus nidos supone una ventaja para el desarrollo de las plántulas (tasa de crecimiento y de foliación) y para su supervivencia (\% de plántulas supervivientes). Se recolectaron semillas de Santiria trimera (Burseráceas), Chrysophyllum lacourtianum (Sapotáceas) y Plagiostyles africana (Euforbiáceas) en las heces de los gorilas y se sembraron en vivero con y sin matriz fecal. Se establecieron plántulas de Santiria trimera y Dacryodes normandii (Burseráceas) en nidos y en bosque de tierra firme con dosel cerrado para evaluar el impacto de la deposición de semillas en el desarrollo y supervivencia de las plántulas. Nuestras observaciones muestran una influencia positiva de la matriz fecal en el desarrollo de las plántulas de las especies estudiadas, pero ningún efecto en su supervivencia. Con respecto a los lugares de deposición, las tasas de crecimiento observadas fueron dos a diez veces más altas en los nidos que en el bosque con dosel cerrado. El mayor desarrollo de las plántulas estaba positivamente correlacionado con la apertura del dosel de copas. Es necesario realizar estudios in situ de germinación de semillas y de crecimiento y supervivencia de las plántulas para caracterizar mejor el destino de las semillas dispersadas por los gorilas. Sin embargo, nuestros resultados aportan evidencias sobre el importante papel de los gorilas en la dispersión dirigida en bosques con dosel abierto.

Palabras clave: Gorilla gorilla gorilla, efecto fertilizante, dispersión dirigida, comportamiento de nidificación, dispersión de semillas, crecimiento de las plántulas, supervivencia de las plántulas, Gabón. 


\section{Introduction}

The majority of tropical plant species (50-95 \%) possess fleshy fruits adapted to vertebrate consumption, and hence animal-mediated seed dispersal (Howe and Smallwood, 1982). The general advantages of endozoochory are escape from distance- and density-dependent mortality under the mother tree (Janzen-Connell effect) (Janzen, 1970; Connell, 1971), colonisation of new habitats and sites, and gene flow among and between populations (Howe and Smallwood, 1982; Howe, 1989, Jansen and Zuidema, 2001; Stoner and Henry, 2008). In addition, endozoochory may lead to directed dispersal in cases when the disperser deposits most seeds in favourable sites (Howe and Smallwood, 1982; Jansen and Zuidema, 2001). Passage through the digestive tract and deposition in faecal manure may also enhance seed dispersal effectiveness (Dinerstein and Wemmer, 1988; Jansen and Zuidema, 2001; Traveset et al., 2001, 2007). The spatial distribution pattern of dispersed seeds depends on disperser physiology (gut passage time) and behaviour (daily path length, habitat use, nesting behaviour, etc.) (Stoner and Henry, 2008; Bueno et al., 2013). Because of these species-specific factors, functional redundancy between two frugivorous species is limited (Bueno et al., 2013, but see Mcconkey et al., 2014). As a result of anthropogenic disturbances, many forest-living animal populations, especially large mammals that provide important dispersal services, are threatened by decline, or even local extinction (Wright, 2003; Andriantsaralaza et al., 2013). Understanding the role of these vertebrates in plant regeneration is important to reveal the potential effects of "defaunation" (Galetti and Dirzo, 2013; Kurten, 2013). Such knowledge is particularly relevant when high value tree species, either used for timber or non-timber products by rural populations, are dispersed by threatened mammals (Daïnou et al., 2012; Rosin, 2014).

Among Central African frugivorous, the critically endangered western lowland gorilla (Gorilla gorilla gorilla Savage and Wyman) (photo 1) is considered a key disperser (Petre et al., 2013). This species disperses seeds in a spatially and temporally bimodal pattern with more than $50 \%$ of seeds deposited at nest sites (Todd et al., 2008), which are preferentially installed in open habitats (Tutin et al., 1991; Rogers et al., 1998; Voysey et al., 1999; Petre et al., 2015a). Seedling growth is enhanced in tree fall gaps, even for shade tolerant species (Howe et al., 1985; Popma and Bongers, 1988 and references therein; Schupp et al., 1989), and a beneficial effect of deposition at gorilla nest sites was observed for three tree species at Lopé, Gabon (Tutin et al., 1991; Rogers et al., 1998; Voysey et al., 1999). As logged forest is one habitat type preferentially selected by gorillas for nesting (Arnhem, 2008), their dispersal services are thought to be critical in the context of logged forests. However, the fate of seedlings remains poorly studied. Some studies showed that seed predation pressure by rodents was higher at tree fall gaps (Schupp, 1988a), while other demonstrated that seedling survival was higher because of a lower pathogen pressure (Schupp et al., 1989). A study in Cameroon demonstrated that seed deposition at gorilla nest sites benefits dispersed seeds as a result of a lower mean burial depth by the dung beetle community, compared to what was observed in closed canopy forest areas (Petre et al., 2015b). These potential advantages brought by seed deposition at nest sites require further investigation and to our knowledge, no study has yet been undertaken to assess the fertilisation effect of the gorilla faecal matrix on seedling growth.

This study assessed the impact of being deposited in a faecal matrix, and at nest site locations, on seedling growth and seedling survival. Specifically, the following hypotheses were tested: (1) the presence of a faecal matrix surrounding the seeds enhances seedling growth and survival; (2) seedling growth is faster and seedling survival is higher at nest sites than at closed canopy terra firma forest sites; (3) seedling survival is lower under a conspecific tree (JanzenConnell effect) (Janzen, 1970; Connell, 1971); (4) enhanced seedling development in open canopy nest sites results from higher light availability.

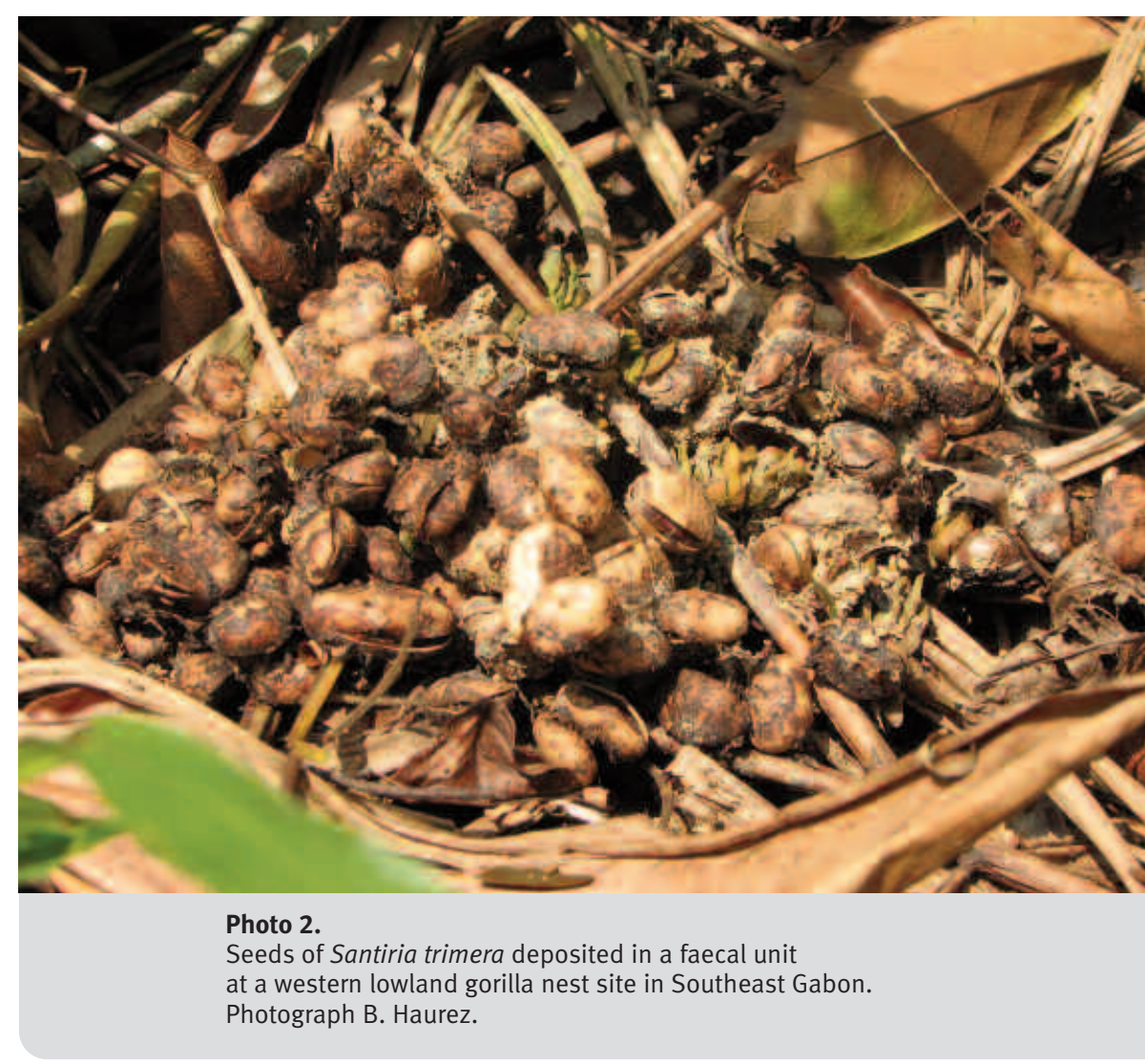




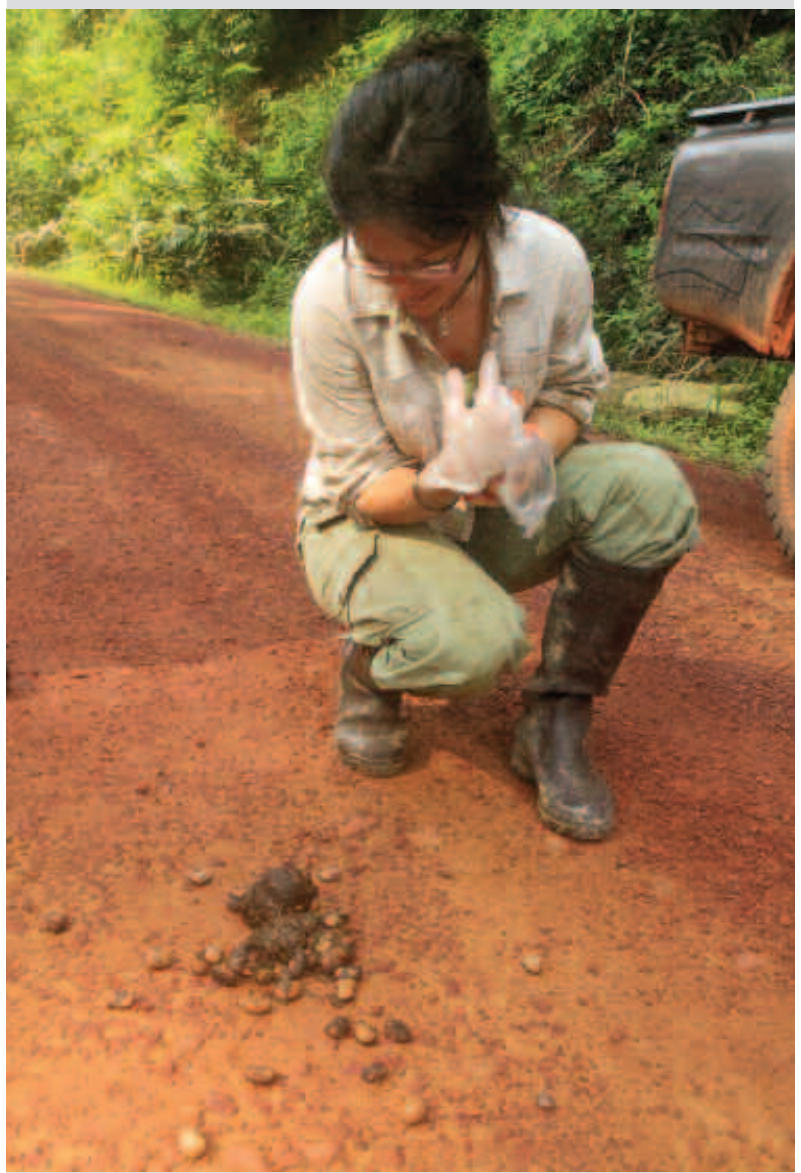

Four tree species typical of the study area were selected: Santiria trimera (Oliv.) Aubrév. (Burseraceae), Plagiostyles africana Prain ex De Wild. (Euphorbiaceae), Dacryodes normandii Aubrév. and Pellegr. (Burseraceae) and Chrysophyllum lacourtianum De Wild. (Sapotaceae) (Doucet, 2003). Their average densities in the logging concession were previously estimated to be $30.2,7.6,1.6$ and 0.20 trees. ha-1 $(\mathrm{dbh}>10 \mathrm{~cm})$, respectively (the density given for $C$. lacourtianum was estimated based on the density of Chrysophyllum spp.) (Doucet, 2003; Medjibe et al., 2013). All are evergreen, shade-bearer (C. lacourtianum, S. trimera and $D$. normandii) or non-pioneer light-demanding species (P. africana) (Doucet, 2003; Petre et al., 2015a). Two (C. lacourtianum and $D$. normandii) are timber species, and

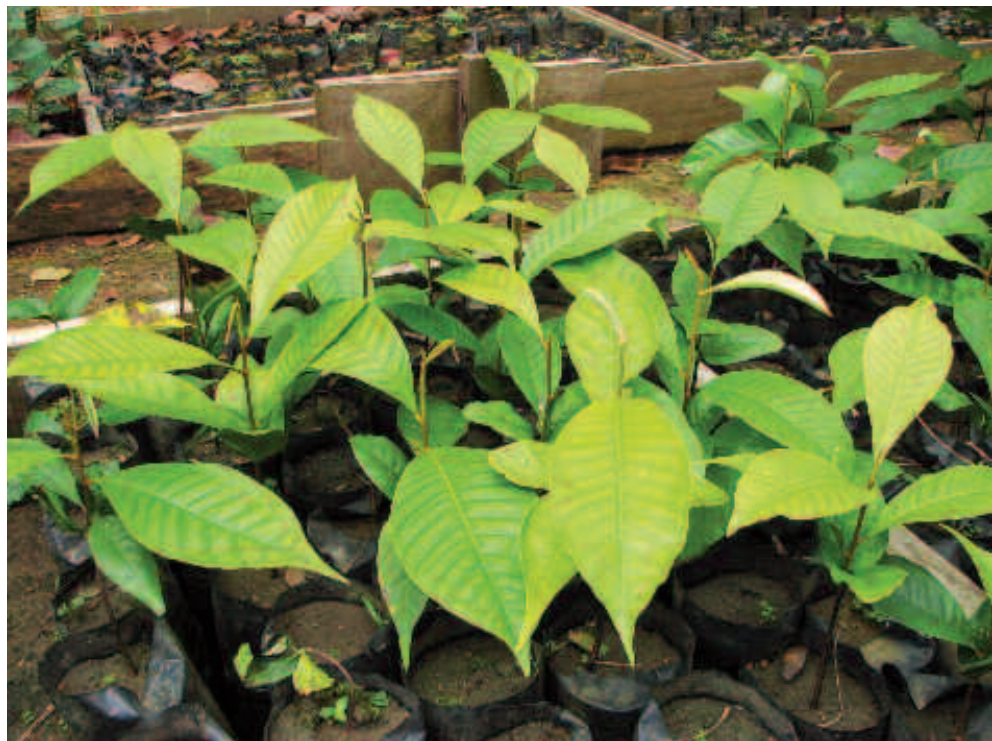

Photo 3.

Seedling of Chrysophyllum lacourtianum growing in a nursery in Southeast Gabon. Photograph B. Haurez.

Photo 4.

Collection of a fresh gorilla faecal unit on a logging road in Southeast Gabon.

Photograph J.-L. Doucet.

the fruits of three (C. lacourtianum, S. trimera and $D$. normandii) are valuable non-timber forest products (NTFPs) (Aubréville, 1962; Lemmens, 2007; Brink, 2008). The four tree species are also used by local populations for various medicinal and cultural purposes (Aubréville, 1962; Lemmens, 2007; Brink, 2008; Schmalzer and Lemmens, 2008). Gorillas consume fruits of these species in abundance whenever they are available and their seeds are not destroyed by passage through the gorilla gut (Fourrier, 2013; B. Haurez pers. obs.; C.-A. Petre, pers. obs.) (photo 2). The use of the different species, as well as the number of repetitions, for our experiments was based on the availability of seeds and faecal matrix, or seedlings at the time of the trials.

\section{Fertilisation effect of faecal matrix on seedling growth and survival}

The fertilisation effect of the presence of a faecal matrix was assessed through seedling growth trials in a nursery for three of the species: C. lacourtianum, $P$. africana and $S$. trimera (photo 3 ). Seeds extracted from gorilla faeces (photo 4) were sown following three treatments: (1) cleaned seeds directly sown in the soil, (2) cleaned seeds placed in a ovoid ball of faecal material (approximately $5 \times 3 \times 2 \mathrm{~cm}$ ). A control treatment was realised for $C$. lacourtianum and $S$. trimera, with seeds extracted from fruits. Because all seeds found under $P$. africana trees were already germi- 
Table I.

Description of the fertilisation effect trials.

\begin{tabular}{|c|c|c|c|c|}
\hline Trial & Treatment & $\begin{array}{l}\text { No. seeds } \\
\text { sown }\end{array}$ & $\begin{array}{l}\text { No. seeds } \\
\text { germinated }\end{array}$ & $\begin{array}{l}\text { No. surviving } \\
\text { seedlings }\end{array}$ \\
\hline \multicolumn{5}{|c|}{ Chrysophyllum lacourtianum } \\
\hline \multirow[t]{3}{*}{ CL1 } & Seed from faeces & 6 & 5 & 5 \\
\hline & Seed from faeces in faecal matrix & 6 & 6 & 6 \\
\hline & Control & 6 & 0 & NA \\
\hline \multirow[t]{3}{*}{$\mathrm{CL} 2$} & Seed from faeces & 1 & 1 & 1 \\
\hline & Seed from faeces in faecal matrix & 1 & 1 & 0 \\
\hline & Control & 1 & 0 & NA \\
\hline \multirow[t]{3}{*}{$\mathrm{CL} 3$} & Seed from faeces & 7 & 6 & 6 \\
\hline & Seed from faeces in faecal matrix & 7 & 7 & 6 \\
\hline & Control & 7 & 0 & NA \\
\hline \multirow[t]{3}{*}{ CL4 } & Seed from faeces & 14 & 14 & 14 \\
\hline & Seed from faeces in faecal matrix & 14 & 12 & 11 \\
\hline & Control & 14 & 7 & 6 \\
\hline \multirow[t]{3}{*}{ CL5 } & Seed from faeces & 12 & 11 & 10 \\
\hline & Seed from faeces in faecal matrix & 12 & 12 & 12 \\
\hline & Control & 12 & 0 & NA \\
\hline \multicolumn{5}{|c|}{ Plagiostyles africana } \\
\hline \multirow[t]{2}{*}{ PA1 } & Seed from faeces & 50 & 37 & 33 \\
\hline & Seed from faeces in faecal matrix & 50 & 34 & 30 \\
\hline \multicolumn{5}{|c|}{ Santiria trimera } \\
\hline \multirow[t]{3}{*}{ ST1 } & Seed from faeces & 6 & 4 & 4 \\
\hline & Seed from faeces in faecal matrix & 6 & 6 & 6 \\
\hline & Control & 6 & 0 & NA \\
\hline \multirow[t]{3}{*}{$\mathrm{ST} 2$} & Seed from faeces & 4 & 4 & 4 \\
\hline & Seed from faeces in faecal matrix & 4 & 4 & 4 \\
\hline & Control & 4 & 1 & NA \\
\hline \multirow[t]{3}{*}{ ST3 } & Seed from faeces & 8 & 0 & NA \\
\hline & Seed from faeces in faecal matrix & 8 & 0 & NA \\
\hline & Control & 8 & 0 & NA \\
\hline \multirow[t]{3}{*}{ ST4 } & Seed from faeces & 8 & 8 & 7 \\
\hline & Seed from faeces in faecal matrix & 8 & 5 & 4 \\
\hline & Control & 8 & 0 & NA \\
\hline \multirow[t]{3}{*}{ ST5 } & Seed from faeces & 3 & 1 & 0 \\
\hline & Seed from faeces in faecal matrix & 3 & 1 & 1 \\
\hline & Control & 3 & 1 & 0 \\
\hline
\end{tabular}

nated, the control treatment was not implemented for this species. Each seed was sown singly in a plastic bag filled with soil collected from the study site. In order to limit the effect of variability of gorilla diet composition on the faecal matrix treatment (as a result of differences in food chemical composition), all faeces to be used in a trial were mixed together before forming the faecal ball. Seed germination was monitored daily. Growth rate $\left(\mathrm{cm}^{\mathrm{day}}{ }^{-1}\right)$, foliation rate (number of leaves.day ${ }^{-1}$ ) and proportion of surviving individuals (\%) were calculated (Popma and Bongers, 1988; Loiselle, 1990) after 12 months. Depending on seed availability, five trials were realised for C. lacourtianum and $S$. trimera, and only one for $P$. africana (table I). Every trial involved seeds coming from the same faeces or the same tree (control treatment) sown on the same day. 


\section{Effect of deposition site on seedling growth and survival}

In order to test the effect of deposition site on seedling growth and survival, nursery-raised seedlings of $S$. trimera (11 months old) and $D$. normandii seedlings (1 month old) were planted in $1 \mathrm{~m}^{2}$ plot, $30 \mathrm{~cm}$ apart (1) at nest sites in open canopy terra firma forest, and (2) in closed canopy terra firma forest. For $D$. normandii, a third treatment comprised seedlings installed (3) in closed canopy terra firma forest under a mature fruiting conspecific. This treatment was undertaken to test for the influence of the proximity to a conspecific on predator and pathogen pressure (Janzen-Connell effect) (Janzen, 1970; Connell, 1971). The surrounding vegetation was kept intact in each plot. For $S$. trimera, two repetitions were performed for each treatment, and for $D$. normandii, four repetitions were performed for treatment 2 and three for treatments 1 and 3. Fifteen seedlings and five seedlings were installed in each plot for $S$. trimera and $D$. normandii, respectively. All the seedlings of a given species were installed the same day. Seedling growth (growth rate and foliation rate) and survival (\% of surviving seedlings) were assessed for $S$. trimera and $D$. normandii after 18 and 9 months, respectively.

\section{Effect of light availability on seedling growth and survival}

Canopy openness was measured at each seedling plot using hemisphere pictures taken with a $4.5 \mathrm{~mm}$ Sigma circular fisheye lens on a Canon EOS D50 camera. Two repetitions of pictures were taken at the centre of the plots between 6.00 and $7.30 \mathrm{am}$, at $1 \mathrm{~m}$ height, with the lens placed vertically on a tripod and the camera oriented North. Shutter speed and aperture were set as to maximize the contrast between the canopy and the sky. Canopy openness was estimated with Gap Light Analyzer 2.0 using a standard image to define the hemisphere circle. A mean measure of canopy openness (\%) was calculated for each plot by averaging the values obtained for the two repetitions. The resulting mean canopy openness value was used as a proxy for light availability at the site.

\section{Data analysis}

Generalized Linear (Mixed) Models or General Linear (Mixed) Models were adjusted to evaluate the effect of (1) faecal matrix and (2) type of site on seedling growth (growth rate and foliation rate) and seedling survival rate. Trial repetitions and plots, respectively, were used as a random factor to take into account potential uncontrolled variability of the response in the initial models, but were discarded when non significant. Depending on the adjusted models, the significance of a factor was assessed by comparing the models with and without the factor with a Chi-square test or an F-test. In order to test the influence of light availability, estimated by canopy openness, on seedling growth rate, foliation rate and proportion of surviving seedlings, Linear Regression Models were performed.

All statistical analyses were performed in $R$ 3.1.3 ( $R$ Core Team, 2012) using the package Ime 4 and the function "glmer" for Generalized Linear Mixed Models, "Imer" for General Linear Mixed Models, "glm” for Generalized Linear Models and "Im” for General Linear Regression Models.

\section{Results}

\author{
Fertilisation effect of faecal matrix \\ on seedling growth and survival
}

These results are displayed in figure 1 . In the case of $S$. trimera, only two seeds under the control treatment germinated, and both seedlings died. Therefore, the control treatment was conserved in the analysis only for $C$. lacourtianum. Seedlings of $S$. trimera and C. lacourtianum showed no increase in growth rate ( $S$. trimera: $\mathrm{df}=1, \chi^{2}=0.65$, $p=0.42$, and C. lacourtianum: $d f=2, \chi^{2}=0.59, p=0.75$ ) but a light increase in foliation rate (S. trimera: $\mathrm{df}=1$, $\chi^{2}=3.91, p=0.048$, and C. lacourtianum: $d f=2, \chi^{2}=6.46$, $p=0.040$ ) in relation to the presence of a faecal matrix. $A$ positive effect of presence of a faecal matrix on seedling growth ( $\mathrm{df}=2$ and 61, $\mathrm{F}=426, \mathrm{p}<0.001)$ and foliation rate (df $=1$ and 69, $F=14.60, p<0.001$ ) was observed for $P$. africana. The presence of a faecal matrix did not affect survival of the tested species (S. trimera: $\mathrm{df}=1, \chi^{2}=0.31$, $p=0.578$, C. lacourtianum: $d f=2, \chi^{2}=1.37, p=0.50$, P. africana: $\left.\mathrm{df}=1, \chi^{2}=0.016, \mathrm{p}=0.90\right)$.

\section{Effect of deposition site on seedling growth and survival}

Table II presents a synthesis of the parameters recorded in the experimental plots. The results related to deposition sites are presented in figure 2 . For both species, the growth rate (S. trimera: $\mathrm{df}=1, \chi^{2}=9.77, \mathrm{p}=0.0018$, and $D$. normandii: $\left.\mathrm{df}=2, \chi^{2}=14.7, \mathrm{p}<0.001\right)$ and foliation rate (S. trimera: $\mathrm{df}=1, \chi^{2}=5.27, p=0.027$, and $D$. normandii: $\mathrm{df}=2, \chi^{2}=18.4, \mathrm{p}<0.001$ ) were significantly related to deposition site. Growth rate and foliation rate of S. trimera seedlings were 10 and two times higher at nest sites than in closed canopy terra firma forest, respectively. For $D$. normandii, seedlings deposited in nest sites presented growth rates about five times faster than in closed canopy forest (both away from and under a conspecific). Foliation rate was approximately 10 times higher at nest sites than in closed canopy forest away from a conspecific. The foliation rate under a conspecific was negative, which could indicate a higher herbivore or pathogen pressure.

Survival of $S$. trimera seedlings was not significantly related to deposition site ( $\left.\mathrm{df}=1, \chi^{2}=0.0024, \mathrm{p}=0.96\right)$. However, a marginal influence was detected for $D$. normandii ( $d f=2, \chi^{2}=5.71, p=0.057$ ), with a lower survival rate at nest sites, and to a lesser extent under a conspecific.

\section{Effect of light availability on seedling growth and survival}

Seedling growth (S. trimera: $\mathrm{df}=1$ and $46, \mathrm{~F}=75.2$, $\mathrm{p}<0.001$, and $D$. normandii: $\mathrm{df}=1$ and $45, \mathrm{~F}=44.4$, $\mathrm{p}<0.001)$ and foliation rate (S. trimera: $\mathrm{df}=1$ and $45, \mathrm{~F}=39.4$, $\mathrm{p}<0.001$, and D. normandii: $\mathrm{df}=1$ and $45, \mathrm{~F}=37.2$, $p<0.001$ ) were positively correlated to canopy openness for both tested species (figures 3 and 4). In light of these results, and those obtained when addressing the effect of type of site, it appears that the potential positive effect of deposition at nest sites on seedling growth (photo 5) was 


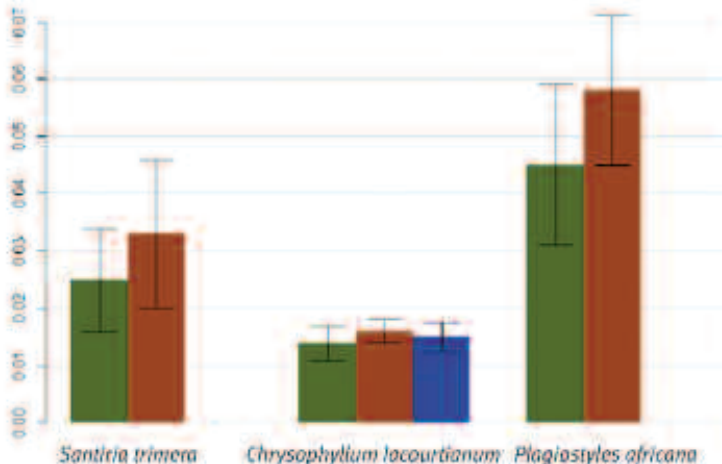

Sonzicia yimera

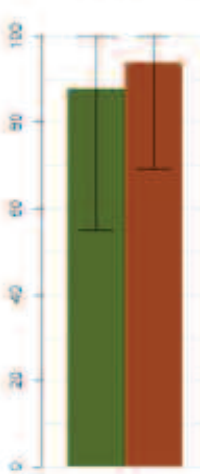

Santria bimero

\section{Survival rate $\{\%$}
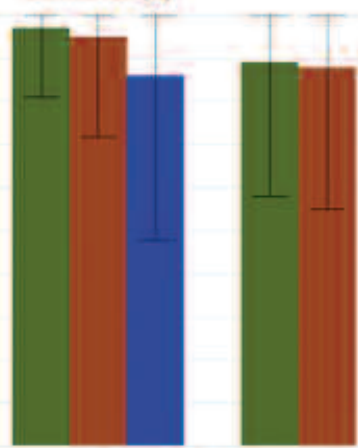

Chysophyliam locourtionem Plaglosivles africano

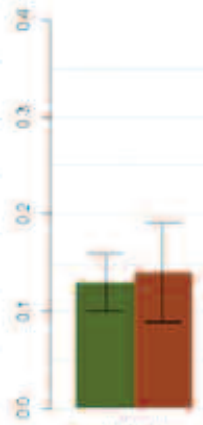

Saniria trimero

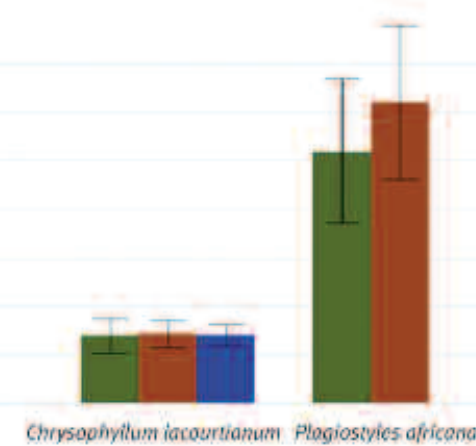

Chrysoofyilum iacoertianum Plagiostvies africana

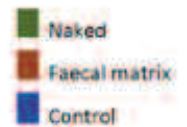

\section{Figure 1.}

Observed seedling growth rate, foliation rate and survival for three tree species dispersed by western lowland gorillas with (Faecal matrix) and without (Naked) the presence of a faecal matrix surrounding the seeds.

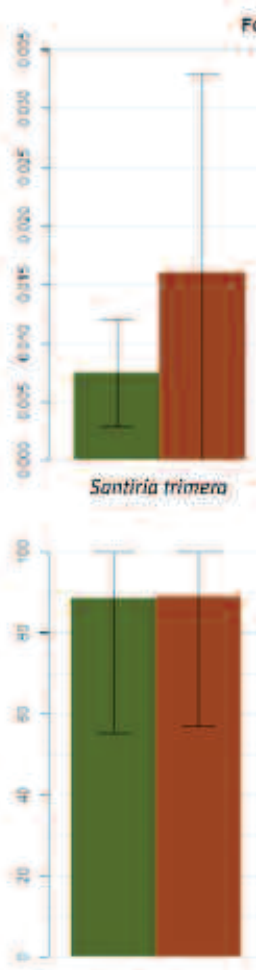

Santiria trimero
Fotiation rate ine. leoves day-1)

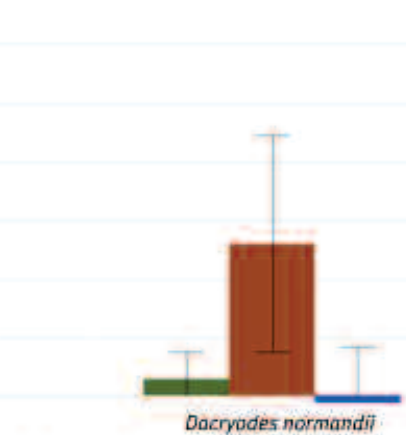

Survival rate (N)

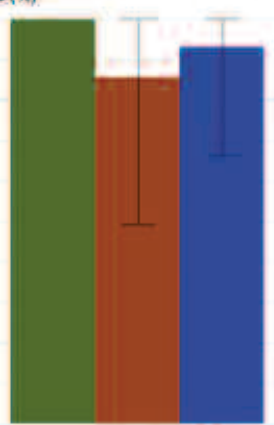

Dacryodes normandit

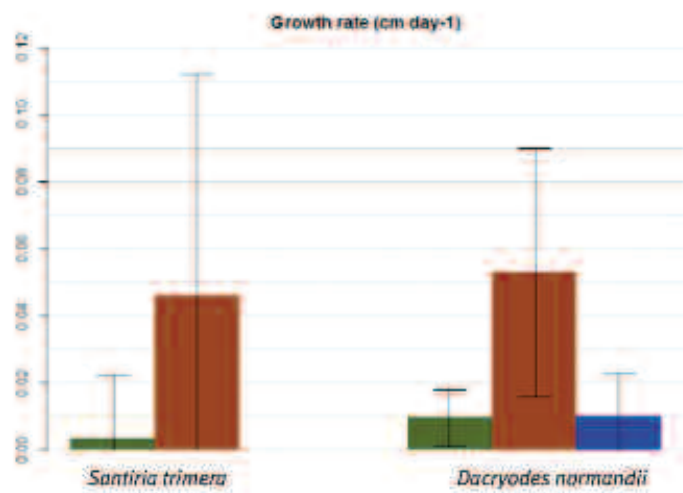

Figure 2.

Observed seedling growth rate, foliation rate and survival for two tree species dispersed by western lowland gorillas deposited at three different types of site (closed canopy forest (Forest), nest site (Nest site) and closed canopy forest under a conspecific (Conspecific)). 
Table II.

Parameters recorded at the different deposition site plots.

Site

Mean canopy openness (\%)

\section{Mean growth} rate $\left(\mathrm{cm}\right.$ day $\left.^{-1}\right)$

Mean foliation rate (no. leaves.day ${ }^{-1}$ )
Discussion

We observed the existence of a positive effect of faecal matrix on seedling growth and foliation rates for Plagiostyles africana, but only a weak effect on foliation rate for Santiria trimera and Chrysophyllum lacourtianum. Gorilla fertilisation effect is therefore species-specific, as demonstrated for other vertebrates (Dinerstein and Wemmer, 1988; Traveset et al., 2001, 2007). Nevertheless, although some differences were not significant, observed mean growth rates and foliation rates for seedlings of all tested species growing within a faecal matrix were higher than that of seeds directly sown in soil. Moreover, the positive effect of manure depends on its composition, with the faecal matrix of frugivorous also consuming animal material being more beneficial than that of dispersers which feed on vegetation only (Traveset et al., 2001). Antagonistic effects have also been observed, as frugivorous manure linked to the light availability at nest sites. However, in the case of $D$. normandii, the addition of the factor "Type of site" explained the variability in foliation rate better than the factor "Canopy openness" alone $(\mathrm{df}=3, \mathrm{~F}=11.83$, $p=0.0080)$; but this was not the case for $S$. trimera $(\mathrm{df}=1$, $\chi^{2}=3.5386, p=0.060$ ). For both species, survival rate was not significantly correlated to canopy openness (S. trimera: $\mathrm{df}=1$ and $51, \mathrm{~F}=1.75, \mathrm{p}=0.192$, and $D$. normandii: $\mathrm{df}=1$ and $48, F=1.12, p=0.295)$. might contain chemical compounds that negatively affect seed germination and seedling survival (Traveset et al., 2001, 2007). Such effects were not observed in our study.

Our results highlight a positive effect of deposition at nest sites on seedling growth and foliation rates for both tested species, Santiria trimera and Dacryodes normandii, particularly in relation to the open canopy conditions of nest sites. Seedlings growing from seeds deposited at open canopy nest sites by gorillas benefit from the higher light

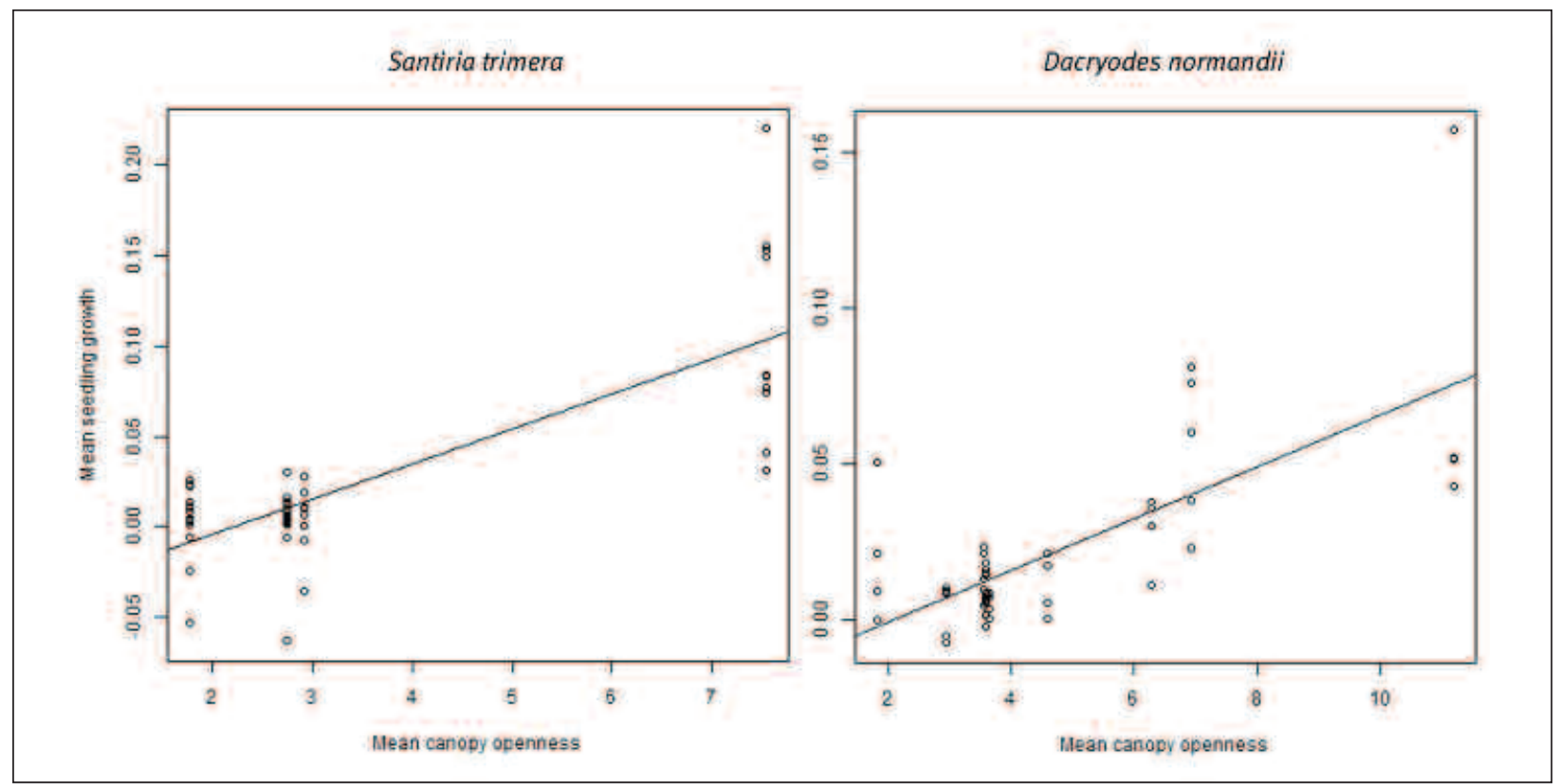

Figure 3.

Graphic representation of the linear model regression of seedling growth in function of canopy openness for the species Santiria trimera $(\mathrm{y}=-0.042560+0.019351 \mathrm{x}, \mathrm{p}<0.001)$ and Dacryodes normandii $(\mathrm{y}=-0.016789+0.008237 \mathrm{x}, \mathrm{p}<0.001)$. 
Santiria trimera

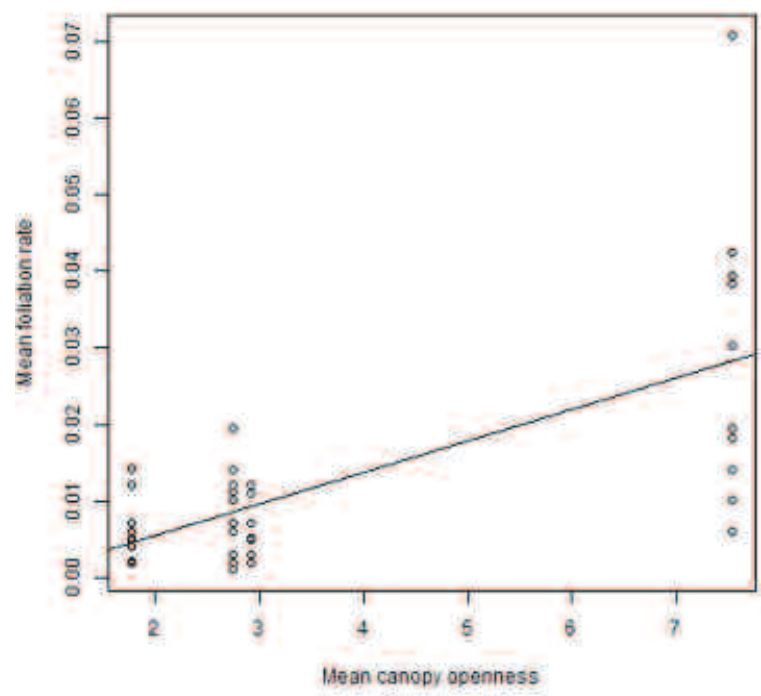

Dacryodes normandii

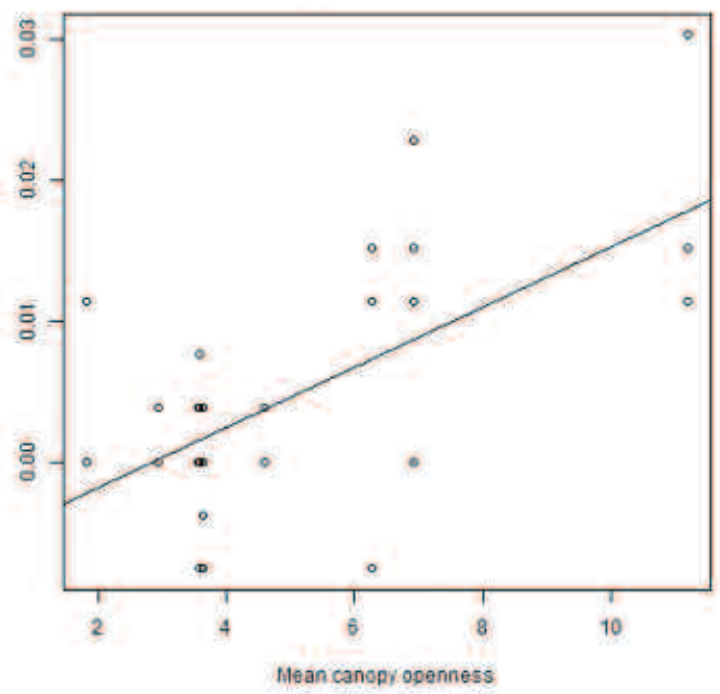

Figure 4.

Graphic representation of the linear model regression of seedling foliation rate in function of canopy openness for the species Santiria trimera $(y=-0.0026593+0.0041168 x, p<0.001)$ and Dacryodes normandii $(y=-0.0060362+0.0021258 x, p<0.001)$.

availability. Seeds deposited at nest sites installed in closed canopy terra firma forest would not experience such an advantage (although a supplementary effect of deposition site on foliation rate and seedling survival is observed for Dacryodes normandii that might be linked to pathogens and/or herbivore pressure). We therefore provide evidence for the "directed dispersal hypothesis" as put forward in Howe and Smallwood (1982). Our study further demonstrates the role of gorillas in directed dispersal of seeds, by depositing seeds most frequently in open canopy sites. The role of gorillas in forest regeneration is therefore highly likely to be essential, particularly as gorillas disperse seeds of many large forest tree species (Fourrier, 2013; Petre et al., 2015a). Open canopy forests, and their associated higher light availability, have also been observed to be advantageous to seedlings of species described as adapted to shade (Howe et al., 1985; Popma and Bongers, 1988 and references therein; Schupp et al., 1989), suggesting subtle effects of light availability on seedling growth (Hatshorn, 1978 cited by Howe et al., 1985). A beneficial effect of both the presence of dung as manure and high light availability on seedling growth was observed for seedlings of Trewia nudiflora L. (Euphorbiaceae) when dispersed by Rhinoceros unicornis L. (Dinerstein and Wemmer, 1988). It is possible that the interaction between faecal matrix and high light conditions would bring further benefits to seedlings originating from seeds dispersed by gorillas. The implementation of in situ seedling development experiments could shed light on such potential interactions.

Dacryodes normandii showed no clear effect of proximity to a mature conspecific on seedlings survival. The Janzen-Connell (Janzen, 1970; Connell, 1971) effect was observed to be highly specific in tropical species (Howe, 1989; Chapman and Russo, 2005). Moreover, this effect might be influenced by the density of adult trees of the con- sidered species within the site, with a satiation of predators occurring at high densities and hampering a distancedependent mortality (Schupp, 1988b). The marginal effect of proximity to a conspecific observed for Dacryodes normandii could indicate a "clump-syndrome" (Howe, 1989; Chapman and Russo, 2005). This is often the case for species dispersed by large frugivorous and therefore adapted to aggregated deposition in faecal clumps (Lambert and Chapman, 2005). Considering the high density and fruit characteristics of Santiria trimera, as well as its tendency to root-graft (Howe, 1989; Doucet, 2003; B. Haurez, pers. obs.), it seems reasonable to suppose that this species also exhibits "clump-syndrome". This "clumpsyndrome" analysis is supported by the observation of many persistent seedlings of $D$. normandii and S. trimera, with no apparent damage, developing from faecal units (B. Haurez, pers. obs.) (photo 6). However, in order to better understand the fate of seeds dispersed by western lowland gorillas, the implications of clumped deposition should also be addressed. Indeed, intra- and interspecific competition for nutrients and light will affect the growth and survival of seedlings dispersed by large vertebrates in this way (Dinerstein and Wemmer, 1988; Loiselle, 1990).

The absence of distance and/or density-dependent mortality might also be due to the fact that the experiments were performed with seedlings and not with non-germinated seeds. Therefore, seed predation by rodents was not assessed in this study. Indeed, the fate of dispersed seeds is influenced by secondary dispersal and post-dispersal seed predation by rodents and dung beetles (Lambert and Chapman, 2005). The study of seed germination, seedling growth and survival in non-disturbed faecal units deposited at nest sites and in the forest along trails would help to characterise more precisely the fate of gorilla-dispersed seeds. 
48 BOIS ET FORÊTS DES TROPIQUeS, 2015, N³24 (2)
Focus / DIRECTED DISPERSAL

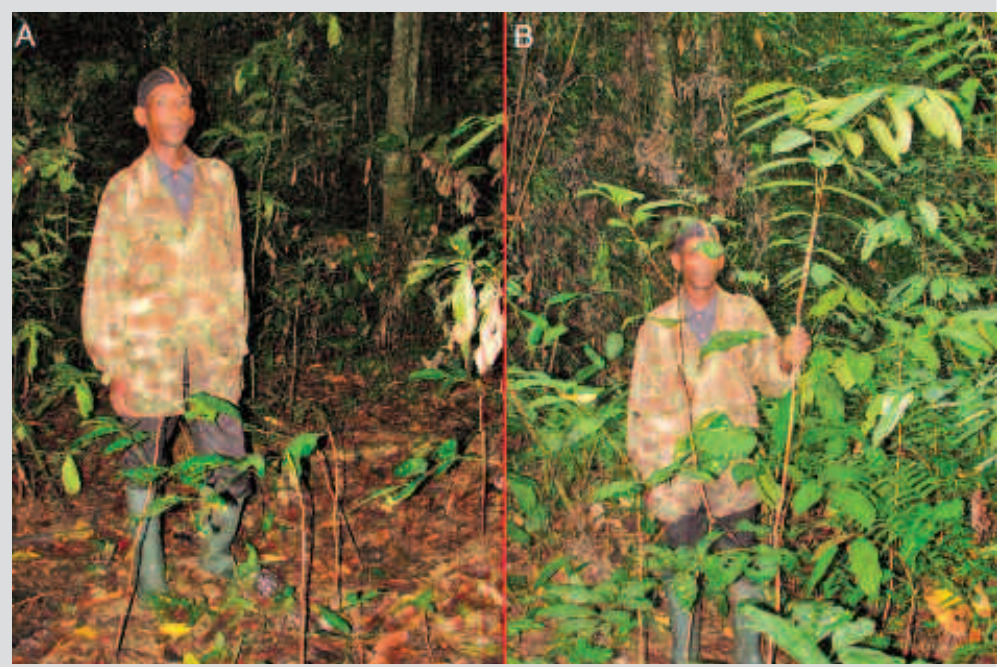

Photo 5.

Comparison of Santiria trimera seedlings installed in (A) closed canopy terra firma forest and (B) western lowland gorilla nest site, after 18 months in Southeast Gabon. Photograph B. Haurez.

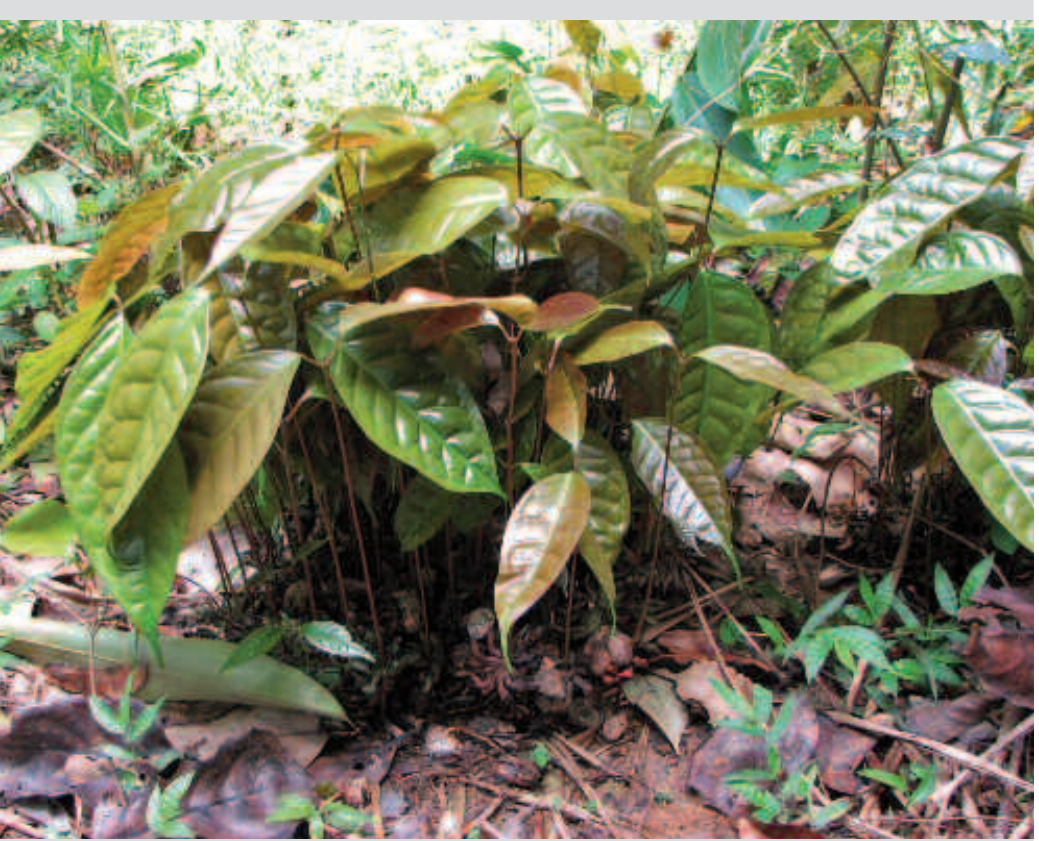

Photo 6.

Cluster of seedlings of Santiria trimera (Burseraceae) developing in a western lowland gorilla faecal unit, Southeast Gabon.

Photograph B. Haurez.

\section{Conclusion}

These results confirm our hypothesis that seedling development is enhanced at gorilla nest sites because of favourable light conditions. Although faecal matrix was observed to enhance seedling development in some cases, its effect seems to be species-specific. We did not detect the existence of a strong Janzen-Connel effect affecting seedlings survival under a conspecific for our tested species.

In this study, we highlighted the impact of gorilla seed dispersal on seedling growth and survival of four tree species, characteristic of the forest of Central Gabon and economically valuable. A number of additional species, which are exploited for their timber and non-timber forest products, also rely on gorillas for seed dispersal (eg. Pseudospondias microcarpa and Trichoscypha spp. (Anacardiaceae), Nauclea didderrichi (Euphorbiaceae), Dialium spp. (Fabaceae), Myrianthus arboreus (Moraceae)) (Fourrier, 2013; Petre et al., 2015a). Therefore, the dispersal services performed by gorillas within the forest ecosystem are both environmentally and economically essential. They are particularly important in the context of logged forest and sustainable forest management.

Although in situ experiments investigating the fate of seedlings emerging from seeds in undisturbed gorilla faeces are required, this study has served to underline the importance of the western lowland gorilla as a seed disperser. Given the growing evidence for its directed dispersal of a wide range of important plant species in tropical forests, the ensured conservation of gorillas is likely to be critical to the maintenance of Central African rainforests and their economic viability.

\section{Acknowledgements}

The Fonds pour la Formation à la Recherche dans l'Industrie et l'Agriculture-Fonds National pour la Recherche Scientifique (FRIA-FNRS, Belgium) provided financial support to Barbara Haurez through a Ph.D. grant. The University of Liège, the Fonds National pour la Recherche Scientifique, the Fonds Léopold III pour l'Exploration et la Conservation de la Nature, the Fonds pour la Formation à la Recherche Scientifique en Afrique, the Fédération Wallonie-Bruxelles, the École Régionale Post-Universitaire d'Aménagement et de Gestion Intégrés des Forêts et Territoires Tropicaux (ERAIFT) and Wallonie-Bruxelles International financed field data collection. Technical and logistical support during the field work of this Ph.D. study were provided by partner structures (Precious Woods Gabon, Groupe Millet and Nature +). We genuinely thank all field assistants who helped in data collection and Dr. V. Medjibe who shared his data with us. We are particularly grateful to Armand Boubady, Noël Endahoyi and Aristide Kouba. We express deep gratitude to Nikki Tagg for her thoughtful correction of the manuscript. Two anonymous reviewers provided relevant comments and ameliorations to this article. 


\section{Bibliographical references}

Andriantsaralaza S., Pedrono M., Tassin J., Roger E., Rakouth B., Danthu P., 2013. The role of extinct giant tortoises in the germination of extant baobab Adansonia rubrostipa seeds in Madagascar. African Journal of Ecology, 52:246-249.

Arnhem E., 2008. Eco-ethological response of great apes and other rainforest mammals to selective logging in Cameroon. Université Libre de Bruxelles, 162 p.

Aubréville A., 1962. Flore du Gabon n 3 Irvingiacées : Simaroubacées, Burséracées. Paris, France, Muséum national d'Histoire naturelle, Laboratoire de Phanérogamie, 101 p.

Brink M., 2008. Dacryodes normandii Aubrév. and Pellegr. In: Louppe D., Oteng-Amoako A. A., Brink M. (eds.). Prota, 7 (1): Timbers/Bois d'œuvre 1. PROTA, Wageningen, Pays-Bas, 210-211.

Bueno R. S., Guevara R., Ribeiro M. C., Culot L., Bufalo F. S., Galetti M., 2013. Functional redundancy and complementarities of seed dispersal by the last Neotropical megafrugivores. PLoS ONE, 8 (2): e56252.

Chapman C. A., Russo S. E., 2005. Primate seed dispersal: linking behavioral ecology with forest community structure. In: Campbell C. J., Fuentes A., MacKinnon K. C., Panger M., Bearder S. K. (eds.). Primates in Perspective. Oxford University Press, Oxford, UK, 510-525.

Connell J. H., 1971. On the role of natural enemies in preventing competitive exclusion in some marine animals and in rain forest trees. In: van der Boer PJ, Gradwell GR (eds.). Dynamics of populations. Proceeding of the advanced study institute, Osterbeek, 1970. Centre for Agricultural Publication and Documentation, Wageningen, 298-312.

Daïnou K., Laurenty E., Mahy G., Hardy O. J., Brostaux Y., Tagg N., Doucet J.-L., 2012. Phenological patterns in a natural population of a tropical timber tree species, Milicia excelsa (Moraceae): evidence of isolation by time and its interaction with feeding strategies of dispersers. American Journal of Botany, 99: 1453-63.

Dinerstein E., Wemmer C. M., 1988. Fruits Rhinoceros eat: dispersal of Trewia nudiflora (Euphorbiaceae) in lowland Nepal. Ecology, 69: 1768-1774.

Doucet J.-L., 2003. L'alliance délicate de la gestion forestière et de la biodiversité dans les forêts du centre du Gabon. Faculté Universitaire des Sciences Agronomiques de Gembloux, 323 p.

Fourrier M. S., 2013. The spatial and temporal ecology of seed dispersal by gorillas in Lopé National Park, Gabon: linking patterns of disperser behavior and recruitment in an Afrotropical forest. Washington University in St. Louis, 242 p.
Galetti M., Dirzo R., 2013. Ecological and evolutionary consequences of living in a defaunated world. Biological Conservation, 163: 1-6.

Haurez B., Petre C.-A., Vermeulen C., Tagg N., Doucet J.-L., 2014. Western lowland gorilla density and nesting behavior in a Gabonese forest logged for 25 years: implications for gorilla conservation. Biodiversity and Conservation, 23: 2669-2687.

Howe H. F., 1989. Scatter-and clump-dispersal and seedling demography: hypothesis and implications. Fcologia, 79: 417-26.

Howe H. F., Schupp E. W., Westley L. C., 1985. Early consequences of seed dispersal for a neotropical tree (Virola surinamensis). Ecology, 66: 781-791.

Howe H. F., Smallwood J., 1982. Ecology of seed dispersal. Annual Review of Ecology and Systematics, 13: 201-228.

Jansen P. A., Zuidema P. A., 2001. Logging, seed dispersal by vertebrates, and natural regeneration of tropical timber trees. In: Fimbel R. A., Gajal A., Robinson J. G. (eds.). The Cutting Edge: Conserving Wildlife in Logged Tropical Forests. Columbia University Press, 35-59.

Janzen D. H., 1970. Herbivores and the number of tree species in tropical forests. American Naturalist, 104: 501-528.

Kurten E. L., 2013. Cascading effect of contemporaneous defaunation on tropical forest communities. Biological Conservation, 163: 22-32.

Lambert J. E., Chapman C. A., 2005. The fate of primate-dispersed seeds: deposition pattern, dispersal distance and implications for conservation. In: Forget P.-M., Lambert J. E., Hulme P. E., Vander Wall S. B. (eds.). Seed fate: predation, dispersal, and seedling Establishment. CABI Publishing, Wallingford, UK, 137-150.

Lemmens R. H. M. J., 2007. Chrysophyllum lacourtianum De Wild. In: Louppe D., Oteng-Amoako A. A., Brink M. (eds.). Prota, 7(1): Timbers/Bois d'œuvre 1. PROTA, Wageningen, Pays-Bas, 180-183.

Loiselle B. A., 1990. Seeds in droppings of tropical fruit-eating birds: importance of considering seed composition. Oecologia, 82: 494-500.

Mcconkey K. R., Brockelman W. Y., Saralamba C., 2014. Mammalian frugivorous with different foraging behaviour can show similar seed dispersal effectiveness. Biotropica, 46: 647-651.

Medjibe V. P., Putz F. E., Romero C., 2013. Certified and uncertified logging concessions compared in Gabon: changes in stand structure, tree species, and biomass. Environmental Management, 51: 524-40. 
Moupela C., Doucet J.-L., Daïnou K., Tagg N., Bourland N., Vermeulen C., 2013. Dispersal and predation of diaspores of Coula edulis Baill. in an evergreen forest of Gabon. African Journal of Ecology, 52: 88-96.

Petre C.-A., Tagg N., Beudels-Jamar R., Haurez B., Salah M., Spetschinsky V., Willie J., Doucet J.-L., 2015a. Quantity and spatial distribution of seeds dispersed by a western lowland gorilla population in south-east Cameroon. Journal of Tropical Ecology, 31 (03): 201-212.

Petre C.-A., Tagg N., Haurez B., Beudels-Jamar R., Huynen M.-C., Doucet J.-L., 2013. Role of the western lowland gorilla (Gorilla gorilla gorilla) in seed dispersal in tropical forests and implications of its decline. Biotechnology, Agronomy, Society and Environment, 17: 517-526.

Petre C.-A., Zinque M.-H., Tagg N., Beudels-Jamar R., Haurez B., Josso J.-F., Moretto P., Doucet J.-L., 2015b. Differences in dung beetle activity at western gorilla defecation sites in south-east Cameroon: implications for establishment of Uapaca spp. Journal of Tropical Ecology, 31: 165-174.

Popma J., Bongers F., 1988. The effect of canopy gaps on growth and morphology of seedlings of rain forest species. Ecologia, 75: 625-632.

R Core Team., 2012. R: A language and environment for statistical computing. R Foundation for Statistical Computing, Vienna, Austria.

Rogers M. E., Voysey B. C., Mcdonald K. E., Parnell R. J., Tutin C. E., 1998. Lowland gorillas and seed dispersal: the importance of nest sites. American Journal of Primatology, 45: 45-68.

Rosin C., 2014. Does hunting threaten timber regeneration in selectively logged tropical forests ? Forest Ecology and Management, 331: 153-164.

Schmalzer G. H., Lemmens R. H. M. J., 2008. Plagiostyles africana (Müll.Arg.) Prain. In: Schmelzer G. H., Gurib-Fakim, A. (eds.). Prota, 11(1): Plantes médicinales 1. PROTA, Wageningen, Pays-Bas, 513-514.

Schupp E. W., 1988a. Seed and early seedling predation in the forest understory and in treefall gaps. Oikos, 51: 71-78.

Schupp E. W., 1988b. Factors affecting post-dispersal seed survival in a tropical forest. Fcologia, 76: 525-530.

Schupp E. W., Howe H. F., Augspurger C. K., Levey D. J., 1989. Arrival and survival in tropical treefall gaps. Ecology, 70: 562-564.

Stoner K. E., Henry M., 2008. Seed dispersal and frugivory in tropical ecosystems. UNESCO, $6 \mathrm{p}$.

Todd A. F., Kuehl H. S., Cipolletta C., Walsh P. D., 2008. Using dung to estimate gorilla density: modeling dung production rate. International Journal of Primatology, 29: 549-563.

Traveset A., Bermejo T., Willson M., 2001. Effect of manure composition on seedling emergence and growth of two common shrub species of Southeast Alaska. Plant Ecology, 155: 29-34.
Traveset A., Robertson A. W., Rodriguez-Pérez J., 2007. A review on the role of endozoochory in seed germination. In: Dennis A. J., Schupp E. W., Green R. J., Westcott D. A. (eds.). Seed dispersal: theory and its application in a changing world. CAB international, Wallingford, UK, 78-103.

Tutin C. E. G., Williamson E. A., Rogers M. E., Fernandez M., 1991. A case study of a plant-animal relationship: Cola lizae and lowland gorillas in the Lope Reserve, Gabon. Journal of Tropical Ecology, 7: 181-199.

Voysey B. C., Mcdonald K. E., Rogers M. E., Tutin C. E. G., Parnell, R. J., 1999. Gorillas and seed dispersal in the Lope Reserve, Gabon. II: Survival and growth of seedlings. Journal of Tropical Ecology, 15: 39-60.

Wright S. J., 2003. The myriad consequences of hunting for vertebrates and plants in tropical forests. Perspectives in Plant Ecology, Evolution and Systematics, 6: 73-86. 